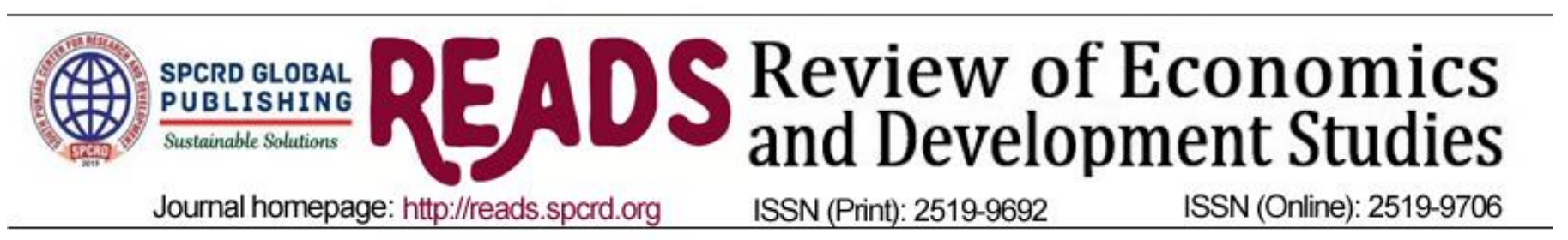

\title{
Measurement of Stock Market Crisis \& its Dimensions: Evidence from Pakistan
}

\section{${ }^{a}$ Mehwish Aziz Khan, ${ }^{b}$ Eatzaz Ahmad}

a Lecturer, Department of Business Administration, Federal Urdu University of Arts, Science \& Technology, Islamabad, Pakistan

${ }^{\mathrm{b}}$ SBP Memorial Chair, School of Economics, Quaid-i-Azam University, Islamabad

\begin{tabular}{l}
\hline ARTICLE DETAILS \\
\hline History: \\
Accepted: o5 May 2020 \\
Available Online: 15 June 2020 \\
\hline Keywords: \\
Stock Market Crisis, CMAX, \\
Intensity Of Crisis \\
\hline JEL Classification: \\
R53, R59, G10 \\
\hline
\end{tabular}

DOI: $10.47067 /$ reads.v6i2.207

\begin{abstract}
This study explores the history of stock market crisis in the emerging market of Pakistan from different perspectives over the period July-1997 to December-2016. To identify and measure the timing of crises occurrence and their various dimensions (magnitude of crisis, days to recovery, duration of crisis, depth of crisis, size of crisis, etc.), CMAX methodology is employed. Thus, the study adds to existing literature by studying the Pakistani market in this regard and also proposing a method to quantify the intensity of crisis (within CMAX framework). The results indicate that the two major crises of 1997-2002 and 20082012 are found to coincide with a number of major financial, economic and political crises in Pakistan and around the world.
\end{abstract}

(C) 2020 The authors. Published by SPCRD Global Publishing. This is an open access article under the Creative Commons Attribution-

NonCommercial 4.0

Corresponding author's email address: eatzaz@qau.edu.pk

\section{Introduction}

Stock market is a platform where the trade of financial assets occurs through stock brokers. It is a part of the financial system and functions as the backbone of the economy of a country since it facilitates both savers and investors to exchange funds and earn income. Proper functioning of stock market makes the financial system sound and the economy grows. However, changing internal and external factors such as political environment, government policies, law and order situation, global factors, integration among international economies and so on may create disturbances in the performance of stock markets. This may paralyze the whole economy in the form of massive losses and stock market crisis may occur.

Financial crises have existed since the time financial markets developed. They vary in their intensity and are usually assessed to measure the size of the economic ellipses. The effects of financial crises spread over a number of sectors, essentially the financial sector. In emerging and developed markets, stock volatility upsurges and stock prices decline throughout the crisis period; however, upshots are more prompt, abrupt and protracted in emerging markets (Patel \& Sarkar, 1998). When a capital market undergoes a major and abrupt drop in stock prices, it is termed as stock market crash 


\section{Review of Economics and Development Studies, Vol. 6 (2) 2020, 289-299}

heading towards an economic or financial crisis. Share prices become prone to unexpected and huge declines.

Therefore, one of the major concerns of analysts, academicians, and practitioners is to investigate when and why the stock market crashes occur. To answer this question, it is essential to define exactly what a stock market crash is. Literature defined it in different ways, for instance, it is an abrupt drop in stock prices below a specific threshold level during a particular time period (Patel and Sarkar, 1998). Stock market crash is also defined as the deviation of market price of a stock from its fundamental value for a long time period (Smith, Suchanek, \& Williams, 1988). Later on, Siegel (2003) and Illing and Liu (2006) supported this definition.

It is important to explain the difference between the two terms: crash and crisis. According to Kole (2006), a significant/huge decrease in price of a single asset, sector or market is called a crash, whereas, crisis is defined as an uncertain period that may affect many assets and many markets. Thus crash may be referred to a single or many days and crisis may be referred to various months. A crisis can be measured in discrete or continuous measures. Discrete measure is represented by a binary variable that describes a crisis to come about when a certain threshold level of specific financial or economic variable is contravened. The difficulty of delineating specific thresholds is overwhelmed by continuous measures of crisis occurrence that evaluate the strength of a crisis on an uninterrupted scale. Real exchange rates, nominal exchange rates, and speculative pressure indices are the examples. Drops in equity market and in GDP are also considered as measures of crisis (Ghosh and Ghosh, 2003). Researchers and practitioners widely focus on the issue of identification of the critical point, that is, the time when the transaction price plunges dramatically (Sornette, Johansen, \& Bouchaud, 1996; Patel \& Sarkar, 1998).

Various approaches to model this unusual price movements or financial crashes are available. Some of these techniques are quite simple. For example, Mishkin and White's (2002) crisis specification, which is commonly used in literature, signifies a crash when the stock market shows a drop of 20 percent or more in price index. Another approach adopted in Al-Rjoub and Azzam (2012) is to apply the Chow breakpoint test to investigate the time of start and end of crash and confirmation of the structural breaks at these points. More sophisticated methods of crisis identification include Cusp Catastrophe proposed by Zeeman (1976), Log Periodic Power Law (LPPL) by Jacobsson (2009), the method of CMAX by Patel and Sarkar (1998).

The frequency of crises in the world has increased in the last decade; for instance, global financial crises of 2007-2008 and more recently the Chinese stock market (an emerging market) turmoil of 2015. Like other markets, the emerging market of Pakistan is also fragile and reactive to upsets and news as the history has witnessed a few financial crises. Therefore, the present study aims to analyze the occurrences and measurement of financial crises in Pakistani stock market during the past 20 years (July 1997 to December 2016). The study adopts conventional approach of CMAX proposed by Patel and Sarkar (1998) to identify the occurrence and duration of crises. It is relatively simpler and has a wide applicability in identifying equity crises, specifying its timing and measuring its magnitude. This technique has not yet been employed for the emerging market of Pakistan. Therefore, following this approach, the study defines a stock market crash as an abrupt slump in an index price below a fixed decline rate as a threshold level specified by Patel and Sarkar (1998).

Each crisis may show a specific pattern, that is, some crises show more depth and small duration (takes less time to recover), some depict low depth but long duration (takes more time to recover), while some may be deeper as well as longer in duration. Therefore, all crises cannot be placed under the 
group of uniform events; each crisis has its own statistical properties. This study attempts to explain pattern of crisis in Pakistan in various dimensions, which includes beginning of crash, beginning of crisis, date of trough, days to trough, days to recovery, date of recovery, minimum and maximum index value during crisis period, duration of crisis, depth of crisis, magnitude of crisis, and size of crisis. The study also proposes a method to quantify the intensity of crisis, that is, to what extent the crisis affects the stock market. The remaining part of this study is organized as follows. Section II presents methodology and data followed by section III, which provides empirical results. Section IV provides a discussion of the results and last section V concludes the study.

\section{Methodology and Data}

\subsection{Identification of Crises}

Log-Periodic Power Law, Cusp Catastrophe and CMAX are three comprehensive techniques to identify stock market crises but CMAX has the advantage of being relatively simple and easily interpretable. Another advantage of the technique is that besides detecting crises, it provides statistical information on a number of dimensions of crises such as duration and magnitude. It detects more crashes, rather than detecting only well-known stock market crashes, and is a more sensitive statistical technique (Vila, 2000) than some of the other known methods. Due to these advantages, CMAX technique is used in the present study.

Literature supports the use of this technique, for instance, Cimpoeru (2015) and Chatterjee, Chiu, Duprey, and Hoke (2017) studied financial stress by using CMAX methodology. Ma, Lee, Lai, and Lee (2017) studied the contributing factors in the occurrence of stock market crisis by CMAX technique.

The first task in CMAX methodology is to detect the date of occurrence of a crash. For this purpose, rolling windows of fixed time duration are used. For daily data, the study selects short windows of 21 days which is the average number of trading days in a month. Then daily stock price index is divided by the maximum price during the past 21 days. This ratio is known as CMAX.

Following Patel and Sarkar (1998), a minimum threshold level is defined to measure the crisis, which is the average of CMAX minus two standard deviations. If the value of CMAX falls below this threshold level, it is considered as a critical decline in the stock index and a crash is supposed to have occurred. The stock market crisis indicator at time $\mathrm{t}, \mathrm{C}_{\mathrm{t}}$ is defined as follow.

$$
\begin{gathered}
\text { CMAX }_{t}=\frac{P_{t}}{\max \left(P_{t-21} \ldots, P_{t}\right)} \\
C_{t}=1 \text { if } C M A X_{t}<\overline{\text { CMAX }_{t}}-2 \sigma_{t} \\
C_{t}=0, \text { Otherwise }
\end{gathered}
$$

The above method describes the way to find out the time when the crash occurred in the history. In order to avoid the double-counting of same crisis, further triggers that occur during a particular crisis are not considered as indicators of new catastrophes and are taken as a part of the existing one.

As discussed above, the study also analyzes some other dimensions of the crises which are as follows. 
- Beginning of Crash $\left(\boldsymbol{C}_{\boldsymbol{t}}\right)$ - When CMAX measure is less than the benchmark of the mean value of CMAX minus two standard deviations, i.e. $C M A X_{t}<\overline{C M A X_{l}}-2 \sigma_{t}$. When this condition holds, a stock market crash is considered to have occurred.

- Beginning of Crisis- The point in time when price index is at maximum within the window of last twenty-one days of the occurrence of crisis.

- Date of Recovery- The date after the crash is triggered, at which price index is equal or greater than pre-crash maximum index level.

- Date of Trough- The date at which price index approaches to its lowest level during the time from the beginning of crisis up to the time of recovery.

- Days to Trough- Number of days after the beginning of the crisis to date of the trough.

- Days to Recovery - Number of days from the date of the trough to date of recovery.

- Maximum Index Value- The maximum price index level from the beginning of the crisis to recovery.

- Minimum Index Value- The minimum price index level from the beginning of the crisis to recovery.

- Magnitude of Crisis- The difference between the maximum and minimum price index values during a particular crisis.

$$
\operatorname{Mag}_{t}=P_{\max }-P_{\min }
$$

- Duration of the Crisis- Number of days from the beginning of the crisis to date of recovery or it can be said that it is the sum of days to trough and days to recovery.

$$
\text { Dura }_{t}=\text { Days }_{\text {Trough }}+\text { Days }_{\text {Recovery }}
$$

- Depth of the Crisis- The difference between pre-crash maximum price index and the average of price index from the beginning of the crisis to date of recovery.

$$
\text { Depth }_{t}=P_{t_{-} \text {Beg of crisis }}-\operatorname{Avg}\left(P_{t_{-} \text {Beg of crisis }}: P_{t_{-} \text {Date of recovery }}\right)
$$

- Size of Crisis- The product of duration and depth of the crisis.

\subsection{Crisis Intensity}

$$
\text { Size }_{t}=\text { Dura }_{t} * \text { Depth }_{t}
$$

The study investigates an important element of crises, that is, crisis intensity, which is calculated by subtracting daily price index value from the pre-crash maximum index value of the crisis under consideration. This measure, given below, indicates the degree to which the market is affected on each day of the crisis.

$$
I N T_{t}=P_{t_{-} P r e-\operatorname{crash} \max }-P_{t}
$$

\subsection{Data}

The price data of Pakistan stock exchange (KSE-10o index) are taken from Yahoo Finance at the daily frequency for the time period of July-1997 to December-2016.

\section{Results}

The CMAX index of the Pakistani stock market is graphically shown in Figure 1 with its threshold level for the time span of July-1997 to December-2016. The index shows significant abnormal occurrences by crossing threshold levels in September-1997, November-1997, May-1998, June-1998, October-1998, May-1999, May-2000, December-2000, October-2001, May-2002, February-2003, 
March-2005, June-2006, May-2008, July-2008, and December-2008. These occurrences can be attributed to various reasons, for instance, sanctions on Pakistan due to nuclear tests in May 1999, the 9/11 attacks, or the global financial crisis of 2007-08.

Table 1 provides information on the dates when the crisis started and the crashes that are found to have occurred in the stock market of Pakistan, along with the information about other dimensions of each crisis. These episodes of crises are analyzed in some detail in the following paragraphs. Note that the crises listed in the table include only those occurrences of stock price index crossing threshold levels that indicate a new crisis, while all such occurrences that took place during a crisis are excluded.

The crash of September-1997: The first crash during the period of analysis occurred on September 1, 1997, which was started a few months back in July-1997. The crisis took 50 days to recover from its pre-crash maximum level. During this time period, the lowest index value was 7.4388 and the highest value was 7.6148. The magnitude of price decline during this crisis was 16 percent $^{1}$. The index moved to trough on September 1, 1997 in 17 days and started to recover on October 21, 1997 taking 33 days for complete recovery. The depth of this crisis was a drop of 8 percentage points from pre-crash maximum index price. As far as size is concerned, it was a drop of 4.02 points in index value in the total duration of the crisis i.e. 50 business days.

The crash of November-1997: The second crash triggered on November 17, 1997. This crisis began in October-1997, which persisted for 1,186 days, the longest stock market crisis (during the time period under consideration). The price index reached to trough on July 14, 1998 in 153 days and took 1033 days to recover from this trough on October 9, 2002. The overall maximum value of price index during this crisis was 7.634 and the minimum value was 6.640 . The magnitude of price decline during this crisis was 62.9 percent. The depth of this crisis was 40.51 percentage points drop from pre-crash maximum and the size was a total drop of 480.47 points in almost 60 months. The additional crashes shown in the Figure 1 that triggered in May, June, and October, 1998; May, 1999; May and December, 2000; October, 2001; and May, 2002 are considered part of the crash of November-1997 because the index level on October 22, 1997 was not recovered till October-2002.

\section{Figure 1. CMAX Index for Pakistani Stock Market}

1 The log price differences are converted to percentage form as follows: $\ln P_{\max }-\ln P_{\min }=0.176$ implies that $P_{\max } / P_{\min }=$ $e^{0.176}=1.192$ or $P_{\min } / P_{\max }=1 / 1.192$. It follows, therefore, that $P_{\min } / P_{\max }-1=0.84-1=-0.16$ or $P_{\text {max }}-P_{\text {min }} / P_{\text {max }}=0.16$. 


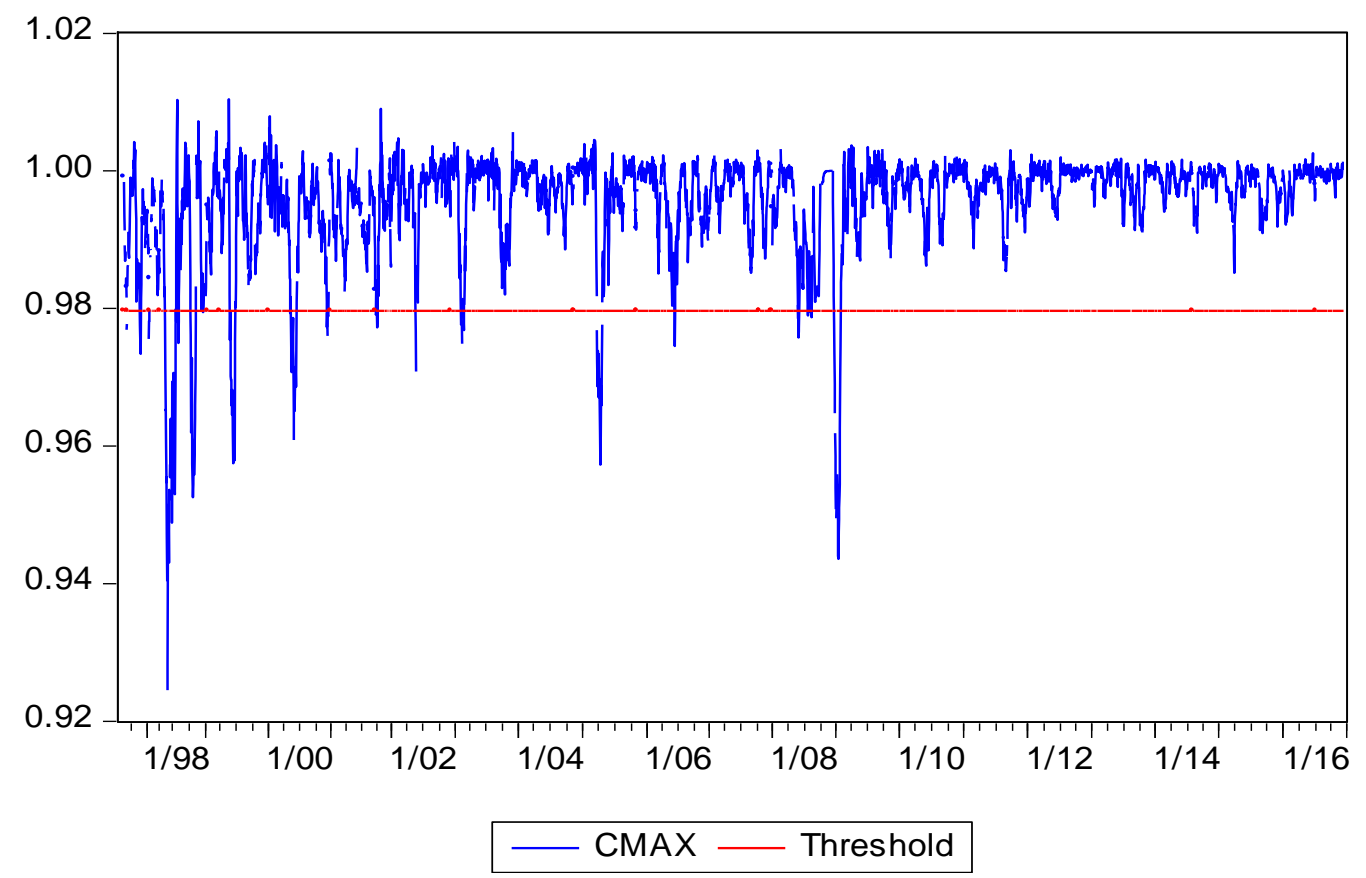

Table 1. Dimensions of Crisis in Pakistani Market

\begin{tabular}{|c|c|c|c|c|c|c|c|c|c|c|c|}
\hline $\begin{array}{l}\text { Beginning } \\
\text { of Crisis }\end{array}$ & $\begin{array}{c}\text { Beginning } \\
\text { of Crash }\end{array}$ & $\begin{array}{l}\text { Date of } \\
\text { Trough }\end{array}$ & $\begin{array}{c}\text { Date of } \\
\text { Recovery }\end{array}$ & $\begin{array}{l}\text { Days to } \\
\text { Trough }\end{array}$ & $\begin{array}{c}\text { Days to } \\
\text { Recovery }\end{array}$ & $\begin{array}{c}\text { Maximum } \\
\text { index }\end{array}$ & $\begin{array}{c}\text { Minimum } \\
\text { index }\end{array}$ & $\begin{array}{l}\text { Magnitude } \\
\text { of Crisis }\end{array}$ & $\begin{array}{l}\text { Duration } \\
\text { of Crisis }\end{array}$ & $\begin{array}{c}\text { Depth of } \\
\text { Crisis }\end{array}$ & $\begin{array}{l}\text { Size of } \\
\text { Crisis }\end{array}$ \\
\hline 29-Jul-97 & 01-Sep-97 & 01-Sep-97 & 21-Oct-97 & 17 & 33 & 7.614 & 7.438 & 0.176 & 50 & 0.080 & 4.02 \\
\hline $22-$ Oct-97 & $17-$ Nov-97 & 14-Jul-98 & $09-$ Oct-02 & 153 & 1033 & 7.634 & 6.640 & 0.994 & 1186 & 0.405 & 480.47 \\
\hline 16-Jan-03 & 03-Feb-03 & $27-\mathrm{Feb}-03$ & 21-Apr-03 & 25 & 34 & 7.991 & 7.764 & 0.227 & 59 & 0.116 & 6.86 \\
\hline 15-Mar-05 & 24-Mar-05 & 27-May-05 & 23-Jan-06 & 51 & 161 & 9.239 & 8.774 & 0.465 & 212 & 0.249 & 52.81 \\
\hline 24-May-06 & 14-Jun-06 & 14-Jun-06 & $17-$ Oct-06 & 15 & 88 & 9.316 & 9.078 & 0.238 & 103 & 0.087 & 9.00 \\
\hline 28-Apr-08 & 26-May-08 & 26-Jan-09 & 18 -Sep-12 & 181 & 908 & 9.647 & 8.479 & 1.168 & 1089 & 0.402 & 438.48 \\
\hline
\end{tabular}

The crash of February-2003: The third crash was triggered on February 3, 2003, which lasted for 59 days. This crisis began from January 16, 2003 and recovered on April 21, 2003. During this crisis period, the stock price index moved to a maximum value of 7.991 and reached a minimum value of 7.764. The magnitude of price decline during this crisis was 20.2 percent. It took 25 days to approach trough on February 27, 2003 and 34 days to starts recovery. The depth of the crisis was a drop of 11.63 percentage points from pre-crash maximum level and size of the crisis showed an overall drop of 6.865 points in 59 business days (or about three calendar months).

The crash of March-2005: The next crash identified was triggered on March 24, 2005 and lasted for 212 days. The crises started on March 15, 2005, took 51 days to reach trough and 161 days to recovery on January 23, 2006. During this crisis, the index approached the maximum value of 9.239 
and a minimum value of 8.774. The magnitude of price decline during this crisis was 37.1 percent. Depth of the crisis was a drop of 24.91 percentage points from the index value at beginning of the crisis. The overall drop was 52.81 points in about 10 months as the size of crisis.

The crash of June-2006: This crash was triggered on June 14, 2006 and had a total duration of 103 days. The start of this crisis was observed on May 24, 2006 and recovery occurred in 88 days on October 17, 2006. During this crisis, the index approaches a maximum value of 9.316 and a minimum value of 9.078. The magnitude of price decline during this crisis was 21.2 percent. The index took 15 days to reach to trough level on June 14, 2006, while and depth of the crisis was a drop of 8.74 percentage points from the index value at beginning of the crisis. The size of crisis showed an overall drop of 9.00 points in about five months.

The crash of May-2008: The last crash in the considered time period of the present analysis was triggered on May 26, 2008. This crisis began on April 28, 2008 and lasted for 1,089 days. It was the second longest stock market crisis in Pakistan after the crash of November, 1997.The price index reached to trough on January 26, 2009 in 181 days, whereas, the index recovered from this trough in 908 days on September 18, 2012. The overall maximum value of price index during this crisis was 9.647 and the minimum value was 8.479. This crisis had the highest magnitude of price decline of 68.8 percent. The depth of this crisis was 40.26 percentage points drop from pre-crash maximum and the size was a total drop of 438.48 points in about 53 months.

\section{Crisis Intensity}

Figure 2 graphically shows the intensity of crises in Pakistani stock market for the time span of July-1997 to December-2016. The figure shows that the crash of May-2008 had the highest single-day intensity. The figure shows that crisis intensity remained very high on a number of days during this crisis. The second most intense crisis by a close margin was that of November 1997 during which crisis intensity remained quite high on a large number of days. On average the two crises seem to show more or less of the same level of intensity. In comparison, all other crises appear to be relatively less intense.

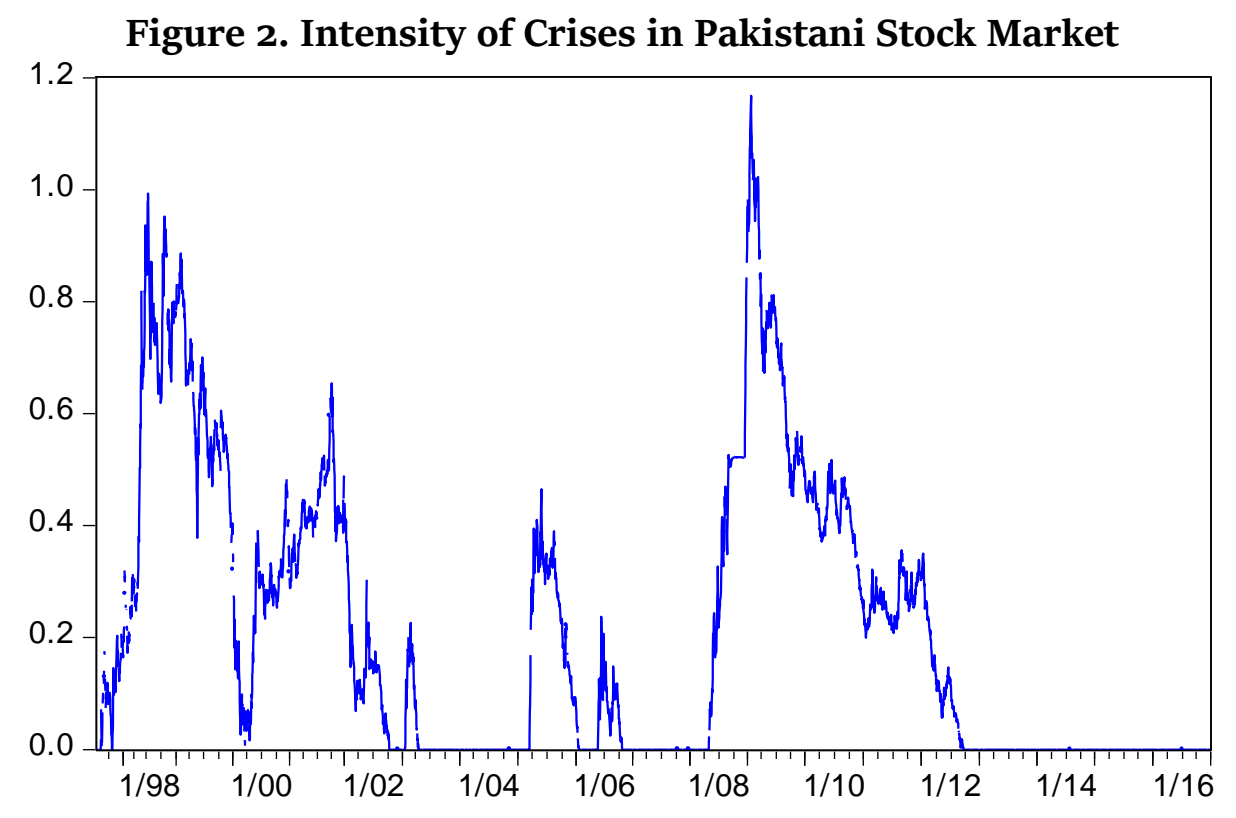

\section{Discussion}

The findings show that CMAX methodology identified the generally agreed popular episodes of historical financial crises, which authenticates its application to Pakistan's stock market. Moreover, 
Review of Economics and Development Studies, Vol. 6 (2) 2020, 289-299

some other small crash episodes are also identified along with them, which are either impression of international crises or independent national-level crises.

The first crash identified in the present study occurred during the time period when the Asian financial crisis influenced the world markets. Asian crisis-1997 resulted in sharp falloffs of stock prices, huge devaluation of currencies, and significant increase in interest rates, which led to substantial amounts of capital outflows from the crisis affected countries. During this period, the economic situation of Pakistan was also showing a downward trend, since the financial sector was in a weak condition and burdened with 'bad debts', low growth in large-scale manufacturing, low external reserves, etc. Pakistan did not experience the adverse effects of the Asian crisis immediately but there were internal constraints and downfalls that dragged the market towards failure. The three main reasons behind this scenario were as follows. First, there was an involvement of more sensitive private sector capital in financing of East Asia boom but in Pakistan, deficit was mainly financed by official flows and private bank deposits which could stabilize the system against balance of payment crisis. Second, foreign currency exposure of the private sector was quite limited and, hence, this sector was unable to attract foreign capital. Third, the introduction of banking reforms in early 1997 helped out to reduce poor credit decision-making, etc. (Khan, 1999).

The crash triggered in November 1997 is found to be the longest one that continued until October 2002 and also had the highest depth and second highest price decline magnitude among all the crises identified in this study. The fiscal year 1997-98 culminated with the sanctions due to nuclear testing by Pakistan and in October 1999 democratically elected government was dismissed by Marshall Law. It was economic, political, and constitutional crisis and also an impact of the Asian crisis. Another important explanation for this downfall was an unjustified act of freezing foreign currency accounts because of the fear of capital outflow (Khan, 1999).

This crash had many episodes when CMAX crossed the threshold level which can be seen in Figure 1 and these episodes mostly occurred in the month of May 1998 at the beginning of summer. The main factor that can explain these episodes was that India and Pakistan became nuclear powers on May $11^{\text {th }}$ and May $28^{\text {th }}$ respectively. This was followed by the international sanctions fiasco and foreign exchange crisis that account for tumbling of KSE-10o index during this month. The effects of nuclear tests by India on Pakistani stock market were more adverse as compared to the effects of nuclear detonation by Pakistan (Javed \& Ahmed, 1999). The adverse consequences of nuclear tests were later magnified by the announcement of financial budget of Pakistan at the start of June, which caused apprehensions about capital markets along with other sectors. Another reason was that several companies were approaching year-end in June and looming economic condition in the wake of nuclear tests by India and Pakistan drove them to stay away from new market operations or managing large portfolios.

In May-1999, another crash episode was seen due to the war like situation between Pakistan and India on the issue of Kargil that triggered the sanctions and deteriorated the investment-friendly country image of Pakistan. The overall performance of various companies was poor with low payout ratios that caused decline in share prices and negatively affected the economy. The change in rules regarding the acquisition of outstanding shares by means of carry-over financing and change in exposure limit requirement in May-200o caused the dumping of shares purchased via such mode. For instance, the market moved downwards as PSO and Adamjee shares dropped like ninepins ("Equity Market," 2002). In May-2001, the weekly clearing system and working procedures were changed and future trading was announced just to monitor the speculation trend. An investigation of two leading 


\section{Review of Economics and Development Studies, Vol. 6 (2) 2020, 289-299}

brokerage houses by the National Accountability Bureau (NAB) declared the involvement of pilfered funds in excessive speculation and adjourned their trading activities. This resulted in a trend of heavy selling and affected the whole market negatively ("Equity Market," 2002).

The attack of September 11 in the US caused a sudden shift in volatility behavior of KSE (Ahmed \& Farooq, 2008). Later on, due to influx of refugees as a result of military action of the US in the neighbor country Afghanistan after 9-11 attack, once again the market showed a downward trend in 2001. The last episode of this second crash happened in May of 2002 due to the unfavorable external factors like tension in Indo-Pak relationships and increased frequency of suicide blasts after 9-11 attacks, especially the suicide blast of May 8, 2002 in Karachi ("Equity Market," 2002). Finally, another factor was that implementation of Corporate Governance Codes 2002 was found too costly by many companies. Some of them delisted themselves, which also negatively influenced overall performance of the market (Fatima, 2016; Khan, 2017).

The crisis in mid of March-2005 that significantly affected the small investors, occurred due to lock-in (a situation when price floors were set for shares prices), impact of circuit breakers and pulling out of funds by financiers of carry-over-trade (Javed, 2007). An exceptional rise in stock market index was seen from December-2004 which continued until March 15, 2005, but an abrupt fall after this date indicated an abnormal behavior of the market. Therefore, poor governance, excessive speculation, and breach of rules were the driving factors behind this crash (Ali, 2017; Raza \& Kemal, 2017).

The next crash of June-2006 was of mild intensity and occurred mainly due to the excessive selling of stocks by investors. The reason was that Pakistan's government faced a strict resistance from investors and could not even strike the last year's projected marginal capital gain tax of 0.001 percent ("Indian Market," 2007).

The last crash occurred in the May 2008, which had the highest price decline magnitude and second highest depth and duration among all the crises identified here. In 2008, Pakistan coped with waning macroeconomic conditions, since current and fiscal deficits arose as a result of increasing oil prices, depreciation of Pakistani currency, depleting foreign exchange reserves, and capital flight. The political condition was also in a transition phase as new democratic government took charge. The new government was unable to handle this poor economic condition and knocked the door of the International Monetary Fund (IMF) (Haq, 2010). Along with these factors, the impression of global selling was also a contributing factor in this recession phase and also the stock market was experiencing a liquidity crunch when investments were diverted to safe investment mode of government's scheme of National Saving Certificates (Haque, 2010; Ali, 2012).

The KSE index plunged with a great loss in market value of \$36.9 billion on August 28, 2008 but it would be difficult to attribute this turmoil solely to any one of the various potential factors including macroeconomic pressures, poor law and order situation, political uncertainty, and global turmoil. In June-2008, the KSE management and Chairman of Securities Exchange Commission of Pakistan (SECP) decided to introduce a circuit breaker (market could fall only up to one percent rather than usual five percent), prohibit short selling to prevent further decline and stop massive exit of investors. On July 14, 2008, old circuit breakers were also reinstated but the market still followed a downward trend, as evidenced by the crash episode of July 17, 2008, shown in Figure 1. The management of KSE with the consent of SECP decided to place a price floor on KSE index at the fixed level of 9144 points instead of using other options of letting the market behave freely or closing the market temporarily. This trapped the investors who wanted to take exit, which was a violation of the free market system (Ali, 2017). But 


\section{Review of Economics and Development Studies, Vol. 6 (2) 2020, 289-299}

when the price floor was revoked on $14^{\text {th }}$ of December-2008, the market was again crashed down to 4782 index points as indicated by CMAX episode of December 19, 2008 shown in Figure 1.

\section{Conclusion}

This study has employed the CMAX technique of Patel and Sarkar (1998) to identifying and measuring crises in the stock market of Pakistan over the period of July-1997 to December-2016. The study finds that CMAX technique has identified all the major stock market crises that are backed by the universally agreed popular episodes of historical financial crisis along with their various dimensions (intensity of crisis, days to trough, days to recovery, duration of crisis, magnitude of crisis, depth of crisis, and size of crisis). This authenticates the effectiveness of CMAX technique in the identification of stock market crashes. Furthermore, some other small crash episodes are also identified, which are either impressions of international crises or independent national-level crises.

The study finds that the crash of November-1997 had more depth and duration and the crash of May-2008 had the highest intensity and price decline magnitude among all the crises identified for the period under analysis. These major market fluctuations violate the Efficient Market Hypothesis (EMH) of traditional finance, that is, investors always perform rationally. Thus the study provides platform to explore such factors, especially the behavioral factors that could cause these market variations.

\section{References}

Ahmed, S., \& Farooq, O. (2008). The effect of 9/11 on the stock market volatility dynamics: Empirical evidence from a front line state. International Research Journal of Finance and Economics, 16, 71-83. Retrieved from http://vbn.aau.dk/en/publications/the-effect-of-911-on-the-stock-marketvolatility-dynamics-empirical-evidence-from-a-front-line-state(1d2175ad-f51b-4do6-8c4eeecdbe6odd2b)/export.html

Ali, K. (2012, November 2). SECP to study 2008 stock market crash. Dawn. Retrieved from https://www.dawn.com/news/761142

Ali, S. I. (2017). Moral neutralization in Pakistan 's capital markets: A study of market abuse (Undergraduate Thesis). The Wharton School, University of Pennsylvania, United States. Retrieved from http://repository.upenn.edu/wharton_research_scholars/154

Al-Rjoub, S. AM., \& Azzam, H. (2012). Financial crises, stock returns and volatility in an emerging stock market: The case of Jordan. Journal of Economic Studies, 39(2), 178211. doi:10.1108/01443581211222653

Chatterjee, S., Chiu, C., Duprey, T., \& Hoke, S. H. (2017). A financial stress index for the United Kingdom. Bank of England Working Paper 697. Retrieved from https://www.bankofengland.co.uk/-/media/boe/files/working-paper/2017/a-financial-stres sindex-for-the-united-kingdom.pdf?la=en\&hash=D4B2767A56E17029181C8D9481

AAB6DF74605AD8

Cimpoeru, S. (2015). The challenge of measuring financial stress. Case study for identifying the macroeconomic triggers of financial crisis with panel data models. Ecoforum, 2(1). Retrieved from http://www.ecoforumjournal.ro/index.php/eco/ article/view/240/140

Equity market and the 'feared' month of May. (2002, June 17). Dawn. Retrieved from https://www.dawn.com/news/43354

Fatima, S. (2016). Corporate governance in Pakistan: Beyond a minimalist approach (Unpublished doctoral dissertation). University of Bedfordshire, United Kingdom. Retrieved from https://core.ac.uk/download/pdf/77037980.pdf

Ghosh, S. R., \& Ghosh, A. R. (2003). Structural vulnerabilities and currency crises. IMF Staff Papers,
Palgrave
Macmillan
Journals,
$50(3)$.
Retrieved
from 


\section{Review of Economics and Development Studies, Vol. 6 (2) 2020, 289-299}

https://www.imf.org/External/Pubs/FT/staffp/2003/03/pdf/ghosh.pdf

Haq, R. (2010, Sep 28). Pakistan's lost decade of the 1990s. Retrieved from https://defence.pk/pdf/threads/pakistans-lost-decade-of-the-1990s.74364/

Haque, I. (2010). Pakistan: Causes and management of the 2008 economic crisis (Global Economic Series No. 22). Penang, Malaysia: Third World Network.

Illing, M., \& Liu, Y. (2006). Measuring financial stress in a developed country: An application to Canada. Journal of Financial Stability, 2(3), 243-265. doi:10.1016/ j.jfs.2006.06.002

Indian market grows faster. (2007, June 9). Dawn. Retrieved from https://www. dawn.com/news/250890

Jacobsson, E. (2009). How to predict crashes in financial markets with the log-periodic power law (Master dissertation). Stockholm University, Sweden.

Javed, A. Y. (2007). Stock market reaction to catastrophic shock: Evidence from listed Pakistani firms. PIDE Working Papers 2007:37. Retrieved from http://pide.org.pk/pdf/Working\%2oPaper/WorkingPaper-37.pdf

Javed, A. Y., \& Ahmed, A. (1999). The response of Karachi stock exchange to nuclear detonation. The Pakistan Development Review, 38(4), 777-786.

Khan, M. Z. (1999). Liberalization and Economic Crisis in Pakistan. Vol. 9 - Pakistan. In Rising to the Challenge in Asia: A Study of Financial Markets (pp. 1-35). Manila, Philippines: Asian Development Bank.

Khan, N. (2017, July 6). KSE-10o index: A post-9/11 appraisal. Daily Times. Retrieved from https://dailytimes.com.pk/3318/kse-10o-index-a-post-911-appraisal/

Kole, E. (2006). On Crises, Crashes and Comovements. Erasmus Research Institute of Management. Retrieved from http://hdl.handle.net/1765/7829

Ma, T., Lee, K. H., Lai, C. H., \& Lee, Y. S. (2017). Rational or Irrational? A comprehensive studies on stock market crashes. doi:10.2139/ssrn.2905555

Mishkin, F. S., \& White, E. N. (2002). U.S. stock market crashes and their aftermath: Implications for monetary policy. NBER Working Paper 8992.

Patel, S., \& Sarkar, A. (1998). Crises in developed and emerging stock markets. Financial Analysts Journal, 54, 50-61. doi:10.2139/ssrn.76168

Raza, S., \& Kemal, M. A. (2017). Daily stock market movements: from the lens of news and events. PIDE Working Papers 2017:146. from http://www.pide.org.pk/pdf/Working\%2oPaper/WorkingPaper-146.pdf

Siegel, J. J. (2003). What is an asset price bubble? An operational definition. European Financial Management, 9(1), 11-24. doi:10.1111/1468-036X.00206

Smith, V. L., Suchanek, G. L., \& Williams, A. W. (1988). Bubbles, crashes, and endogenous expectations in experimental spot asset markets. Econometrica, 56(5), 1119-1151. Retrieved from http://www.jstor.org/stable/1911361

Sornette, D., Johansen, A., \& Bouchaud, J. P. (1996). Stock market crashes, precursors and replicas. Journal de Physique I, 6(1), 167-175. doi:10.1051/jp1:1996135

Vila, A. (2000, March). Asset price crises and banking crises: Some empirical evidence. BIS Conference Paper, 232-252.

Zeeman, E. C. (1976). Catastrophe theory. Scientific American, 234(4), 65-83. doi:10. 1038/scientificamericano476-65 